\title{
Scientific collecting in Malawi, a response to Dowsett-Lemaire et al.
}

\author{
JOHN M. BATES and GARY VOELKER
}

\section{Summary}

We present a response to Dowsett-Lemaire et al. regarding their contention that there is a "new threat" posed by scientific collecting in Malawi and elsewhere.

\section{Introduction}

Successful conservation relies on identifying, prioritising, and mitigating serious threats to populations. Success will depend to a large extent on how well we understand the biology of species and the ecosystems they inhabit, and we believe conservation activities must include long-term and not just short-term monitoring (i.e. evolutionary time versus the next few years or decades). Along with many collaborators and colleagues, we have conducted scientific collecting around the world with the goal of gathering modern data in the form of specimens documenting genotype and phenotype, as well as parasites and pathogens. We sample at the level of populations. The basic biological knowledge gained from these modern scientific collections has important conservation implications for identifying and prioritising threats to populations (e.g. Kahindo et al. 2007, Voelker et al. 2010a,b, Voelker et al. 2013).

Much of our recent work has focused on Africa, in particular Malawi. First and foremost, we emphasise that our work in Malawi is collaborative with the goal of gaining a better understanding of Malawi's birds, while building capacity at the Museums of Malawi and in the protected areas where we have worked. Our research in Malawi began in response to an advertisement in the Ornithological Newsletter of the Ornithological Societies of North America in which the Museums of Malawi requested assistance in developing their collections and research capacity to study Malawi's birds.

In their recent paper, Dowsett-Lemaire et al. (DLEA hereafter) contend that our scientific collecting represents a "new threat" to the birds of Malawi (and Africa broadly). They support their contention by presenting the numbers of specimens that we collected of common forest birds and total numbers of specimens collected in regions spread across Malawi. They argue that we should not have collected individuals of several uncommon species. However, DLEA present no evidence that scientific collecting actually constitutes a threat to any species discussed.

Scientific collecting is something that has and always will be anathema to some people, and this is truer for scientific collection of birds than almost any other group of organisms. However, natural history collections form a substantial foundation for our understanding of the earth's biodiversity. DLEA recognise that there is value to collections, just not modern ones. Too often people, including members of the conservation community, do not appreciate the role that modern collections can and will continue to play in our broader understanding of avian biology across all disciplines. The need for scientific collecting continues because such collections provide not only a temporal benchmark, but also because new research and analytical approaches that can use these collections in new ways continue to be developed. 
The thesis of DLEA's commentary is that our collaborative scientific collecting work in Malawi (and that of all "western institutions" collecting anywhere in Africa) constitutes a "threat" to bird species and populations. If this were true, we simply would not do it. Below, we use our own data as well as those presented by DLEA to support our argument. We have collected series of common bird species as part of ongoing comparative assessment of populations at multiple scales (local, regional, national, and continental) from sites across Malawi. We recognise the size of some series gives pause. DLEA present the numbers for the greatest sample sizes of any species we have collected.

DLEA cite long-term experience and detailed studies of breeding biology that they have done as the primary basis for their opinions. We respect their experience, but emphasise that team leaders associated with all our field programmes also average more than 20 years' experience in tropical lowland and montane forests of Africa and Madagascar as well as three other continents. We have worked in many types of forest including forest fragments (e.g. Bates 2000, 2002), and we are very experienced with mist-net capture rates, which is the method by which larger series of common birds were obtained.

At the time that The Birds of Malawi (Dowsett-Lemaire and Dowsett 2006) was published, there were no published phylogeographic studies of any kind for any bird species (and only one or two for any animals) occurring in the country. Our interest in gathering such data for Malawi is based on the fact that it lies in a transition zone at multiple biogeographic and ecological levels. Many of these connections are discussed by Dowsett-Lemaire and Dowsett (2006), but have not been assessed with genetic data or modern morphological analyses. Extensive and long-term, human-induced habitat change and its effect on birds is also an area of active research for us. We have gathered genetic data on a number of species and are using these data to test hypotheses of connectivity and biogeography in the region. These collections have also formed the basis of the dissertation research of Malawian Potiphar Kaliba (University of Cape Town, South Africa), and Sri Lankan Sampath Lokugalappatti (University of Stellenbosch, South Africa). Sampling of taxa such as Bradypterus warblers has been added to extensive datasets collected by Congolese colleague Charles Kahindo (Ph.D., Makerere University, 2005), and samples from many species have been, and are being, included in broader analyses of the systematics and biogeography of African birds (e.g. Outlaw et al. 2007, Voelker et al. 2010a, b, Oatley et al. 2012, Voelker et al. 2012). Results of these studies directly document biodiversity, in terms of both differentiation between populations and variation within populations, and will have a positive influence on conservation efforts in the region.

As DLEA have presented, when we encountered high rates of capture for a few species for which we had broader study goals (e.g. Starred Robin, Pogonochicla stellata and Yellow-streaked Greenbul, Phyllastrephus flavostriatus alfredi and other greenbul species), we collected series of sizes that would allow for strong statistical comparisons at multiple landscape scales for both genetic and morphological studies. When these Malawian samples are combined with samples taken throughout the montane regions of Africa (where in many cases, we and colleagues at other institutions have assembled modern sampling from long-term field efforts), this will allow for a comprehensive assessment of the population genetics across the species' range (e.g. Bowie et al. 2006, Kaliba unpubl. data, Lokugalappatti unpubl. Ph.D. dissertation) and thus will allow us to characterise, among other things, whether populations should be considered separate conservation units/species (e.g. Voelker et al. 2010b, Engel et al. 2014). As DLEA note, some of the forest species they are concerned about have restricted ranges, but they are common in their specific habitats (e.g. Mzumara et al. 2012). DLEA further note that there are questions related to the possibilities of gene flow between local areas (5-30 km apart). The larger sample sizes we collected for some species as reported by DLEA for a "site" like Misuku Forest Reserve and Nyika National Park include sampling at multiple sites across landscapes to address questions of connectivity between populations in locally isolated forests.

DLEA ask why we should not simply collect blood? Taking blood alone restricts the ability to broadly address important evolutionary questions, and we encourage readers interested in this 
subject to see Bates et al. (2004). DLEA also argue that we could have studied earlier collections. We agree with DLEA about the value of previously collected museum specimens, but we emphasise that these modern specimens are complementary, not an alternative, to older specimens (e.g. Voelker et al. 2010a). Our view is that it is of scientific and conservation interest to compare both morphology and molecules of populations of multiple Malawian species housed in various museums that were collected 6o years ago with modern sampling to better understand the effects of human-induced climate change on birds in Malawi (see discussion of Mortiz et al. 2008 below). While we do hope to conduct research on such questions, we also would envision that future Malawian students will take up such projects as well, because in doing so, science and conservation in Malawi will benefit.

The sections below are organized around the following DLEA concerns about our scientific collecting: I) Collecting was done during the breeding season, 2) Population sizes were small in isolated forests, 3) Collecting was done in protected areas, 4) Modern scientific collecting in Malawi is unnecessary, and 5) The Field Museum should set a better example for Malawi's conservationists.

\section{Collecting during the breeding season}

We are convinced that the collecting we have done during the breeding season is highly complementary and informative when compared with the breeding survey data collected by others such as Dowsett and Dowsett-Lemaire (1984, 1986). Indeed, DLEA have studied our on-line specimen data in some of the same ways as we have. As DLEA note, we have not found more than a few individuals in breeding condition in any of the series of any species we have collected at any site with the exception of Common Bulbul Pycnonotus barbatus, which appears to have reproductively active birds during most seasons at most sites. Thus, our data on breeding condition of populations of common forest species (including Starred Robin Pogonocichla stellata and Yellowstreaked Greenbul Phyllostrephus flavostriatus) illustrate new information about avian population biology in high quality habitat patches. Our data indicate that, for these species, actual breeders generally represent a small percentage of populations in such habitats during a given breeding season. We do not think this would have been obvious under most long-term ringing studies (and DLEA review their own work on this subject).

The following DFLA statement illustrates their apparent inability to accept data that might contradict their preconceived notions: "In the Starred Robins that were collected, we suspect that more females would have been at more advanced stages of breeding and that this was not (or could not be) noted."

We carefully measure the gonads of almost every bird we collect. We have extensive experience doing this, and there is simply no chance to overlook breeding females when specimens are collected. The data DLEA downloaded from our online database clearly illustrate that a very low ratio of female Starred Robins ( $4 / 30$ at Misuku and o/10 at Ntchisi) were in active breeding condition during the peak of the breeding season. Since they are unwilling to accept this, they miss the actual important scientific questions that arise through comparison with their own data based on capture and recapture (and assessment of brood patches). Why did we find so few breeding season birds in breeding condition in our sampling when they found so many in their studies on the Nyika Plateau? We have several possible explanations.

Unlike DLEA, we accept that both sets of investigators are experienced at assessing breeding condition of birds (e.g. brood patches). We strongly suspect that our field approach under-samples breeding birds because we do not move nets around to specifically target large numbers of breeders. At the same time, one explanation could be that our approach maximises sampling of non-breeding birds because nets left in the same place over a period of time capture non-breeding "floaters" in a population. An alternative is that we sampled these birds at the height of a region-wide population cycle when populations were much greater than the years that Dowsett and Dowsett-Lemaire (1986) sampled. But the fact that our sampling uncovered similarly high 
frequencies of non-breeders in forests from different parts of the country in different years makes this possibility unlikely. Another possibility is that breeding seasons have begun to shift in these populations (or that a large portion of the population was foregoing breeding in the years we studied). These hypotheses are worthy of investigation, but they only come to light when suitable data are available. Thus, these specimens document numbers of non-reproductive birds in the breeding season which does not agree with previous findings of Dowsett (1985) and Dowsett and Dowsett-Lemaire (1986), and this novel finding based on collecting in the breeding season suggests there is more to be learned about the breeding biology of these forest species.

\section{Population size estimates in isolated forests}

It also is important to recognise that population size estimates of many bird species, both common and presumed uncommon, in tropical forest patches are underestimates of the actual population size. Using capture/recapture data, recently published research by Mzumara et al. (2012) on the Malawian endemic Yellow-throated Apalis Apalis flavigularis on Mount Mulanje estimated that the population of this species exceeded 10,00o individuals. Bird Conservation International's website cites Mzumara et al. (2012) and goes on to say that a new mining concession has been granted for the whole of Mt. Mulanje. We agree with what is written on the website that this new mining concession could "have disastrous implications for the long-term survival of the species." This could be a real threat.

Ironically, the only examples in the entire DLEA paper that may suggest evidence of threats from collecting are several examples based on their experiences, but not based on anything done by western museums. This includes Abyssinian Hill Babbler (Pseudoalcippe abysinnica) in the Mangochi Hills, where Dowsett-Lemaire reports she subsequently was unable to find more than three pairs 11 years after R. Dowsett collected of II individuals (Dowsett and Hunter 1980). However, if there truly was a decline in this species, the time interval between sampling makes it impossible to determine if collecting or something else was the actual cause. This is an isolated population of a species that, in our experience, is not overly dense (as compared to greenbuls and Starred Robins). We recognize that such low-population density species are an issue with collecting series (Collar 2000, Winker et al. 2010) and we avoid doing this for such species. In forest sites such as Ntchisi Forest Reserve, we have employed a net line in a corner of the forest (not frequented by human visitors). These net lines sample a limited portion of the forest and many individuals were released (including individuals of the species for which we have collected the largest series). Furthermore, throughout our work in Ntchisi Forest and elsewhere, we monitored species in other parts of the forest. This combined with data documenting we were not catching birds in breeding condition made us confident that we were not harming populations.

As we report below, netting (without collecting) at Ntchisi using the same net line, four years later, yielded similar capture rates of common forest species. Based on their own research, DLEA report that annual mortality was "only 13-22\%" (citing Dowsett 1985) for Malawian forest birds. We acknowledge that annual mortality is going to vary by year, site, population and species, but we suspect that these estimates can be taken as a typical range of values for most forest species. Thus, on average, mortality in a population as small as 300 birds is $39-64$ individuals each year. What these estimates illustrate is that a stable population of even a locally common bird does indeed have substantial capacity to sustain itself in the face of the collecting we have done (and common species have populations much greater than this). Using DLEA's own minimum annual mortality rate, the Mulanje populations of Apalis flavigularis must be replacing 1,300 individuals annually based on the total population size estimates of Mzumara et al. (2012). DLEA express concerns about the 15 A. flavigularis we collected on Mulanje in 2006, but the previous numbers illustrate that this does not present a threat. Potiphar Kaliba's dissertation (Kaliba 2014) on genetic and morphological differentiation within this species, which also occurs on the Zomba plateau (where six specimens were collected) highlights the value of these series from a morphological and genetic perspective. 


\section{Collecting in protected areas}

Collecting in protected areas is something that will always be controversial; yet we strongly believe that such sampling is essential for adequately documenting the past (phylogeography), the present (in terms of modern data and additional types of sampling associated with each specimen) and the future (because the data and samples collected today represent an essential baseline for assessing change through time, e.g. adaptation, response to pathogens, changes in parasites and pathogens, and genetic diversity). When available, such data are hugely valuable for conservation. Collections of small mammals and birds in national parks of the western United States are providing some of the most powerful evidence of how elevational shifts in the distributions of multiple species are correlated with climate change in these protected areas (Mortiz et al. 2008). The sampling that we have done in Malawi and elsewhere in Africa (e.g. Uganda) is providing the same kind of essential baseline data for ongoing and future ecological and evolution monitoring of many common birds (Kahindo et al. 2007).

DLEA seem to agree that sampling for pathogens is acceptable (several of that paper's authors have been involved in sampling for avian flu in Malawi; see below). Pathogens and parasites do not recognize protected area boundaries. Thus, responsible long-term monitoring of all animals should involve periodic sampling in protected areas, and we emphasise that baseline data can be essential to any epidemiological study. Host specimens permit correlation of infection rates and pathogens with the phenotype of the infected organism. As better tools for studying disease are developed, the host specimens and their associated parasites and pathogens are the gold standard resources for these fields.

We have been granted collecting permits from the Malawi government based on our argument that collecting inside (and outside) the country's protected areas will provide data that can be used to strengthen protection and conservation programs based on new information (that will continue to be gathered over many years). Furthermore, contrary to the views of DLEA, we believe that collection-based knowledge is a productive way to communicate the importance of the region's biodiversity to the general public.

DLEA have noted that we have unpublished data that might address their concerns about the actual effects of collecting on populations. To quote them:

"J. Bates apparently found the greenbul Phyllastrephus flavostriatus alfredi was still common when he revisited Ntchisi in 2009 (J. Bates in litt. to an anonymous correspondent, in litt. to FDL via N. Baker, 2010). This needs verification"

We can verify this. In the quote above, DLEA allude to data we collected that may be the only truly direct data about the effects of our scientific collecting presented in either one of these papers. In September 2009, for one day and one morning ( 13 hours total), Bates, P. Kaliba and colleagues ran a line of 15 mist nets (each $12 \mathrm{~m}$ long) along the exact same transect as in 2005. We cut the tip of a single tail feather for each individual bird captured to identify recaptures, and thus avoided double-counting recaptured individuals in our calculations. We compare these results to the first two days of captures from 2005 (17-19 nets, 20 hours total) when specimens were collected. To make the data comparable, we calculated capture rate per 1,000 net hours for the two years.

Our results (Table 1 ) show that in 2009, common forest species were captured at similar rates to 2005. This supports our contention that populations in 2009 were similar to those before the scientific collecting done in 2005, and our assertion that populations of these forest bird species were unaffected by our collecting.

Using recently improved Google Earth imagery for the region, we estimate forest area at Ntchisi as roughly 300 ha in size (DLEA report the size as $250 \mathrm{ha}$ ). We consider our estimate to be conservative because the area of a steep forested slope on the north side of the reserve is underestimated using satellite imagery (D. Moyer pers. comm.). Based on work on the Nyika Plateau (Dowsett 1985), DLEA suggest that there are 2-3 breeding pairs of Yellow-streaked Greenbuls per Io ha of forest. If there were no non-breeding individuals, this would mean there were in total 
Table 1. Birds captured per 1,000 mist-net hours from the same site in Ntchisi Forest Reserve four years apart. The number of mist-nets for the two years was 15 (2005) and 19 (2009), see text.

\begin{tabular}{lllll}
\hline Species & $\begin{array}{l}\text { Number of individuals } \\
\text { caught in the first two } \\
\text { days of netting, 2005 }\end{array}$ & $\begin{array}{l}\text { Number of individuals } \\
\text { caught over two days } \\
\text { of netting, 2009 }\end{array}$ & $\begin{array}{l}\text { Birds/net-hours, } \\
2005(368.75 \\
\text { net-hours) }\end{array}$ & $\begin{array}{l}\text { Birds/net-hours, } \\
2009 \text { (195 } \\
\text { net-hours) }\end{array}$ \\
\hline $\begin{array}{l}\text { Pogonocichla stellata } \\
\text { Andropadus virens }\end{array}$ & 28 & 11 & 0.0759 & 0.0564 \\
$\begin{array}{l}\text { Phyllastrephus } \\
\text { flavostriatus }\end{array}$ & 12 & 9 & 0.0271 & 0.0462 \\
$\begin{array}{l}\text { Phyllastrephus } \\
\text { milanjensis }\end{array}$ & 9 & 11 & 0.0325 & 0.0564 \\
$\begin{array}{l}\text { Phyllastrephus placidus } \\
\text { Nectarinia olivacea }\end{array}$ & 14 & & & \\
Hypargos niveiguttatus & 6 & 3 & 0.0244 & 0.0154 \\
Zoothera gurneyi & 5 & 4 & 0.0380 & 0.0205 \\
\hline
\end{tabular}

$120-180$ birds in the forest. In our experience, this is a substantial underestimate of the actual population size. We encountered this species throughout the entire forest in groups of 4-8 individuals. If we take six as the average group size and assume $2-3$ flocks per 10 ha, then this size is $240-480$ birds. Overall numbers also can be estimated another way: we collected 30 birds in 2005 , by sampling an area that was probably much less than 10 ha ( $1 / 30$ of the forest), the population estimate based on these numbers would be goo birds.

A related issue brought up by DLEA is collecting around people. We strive never to make collections in places where we may offend people or negatively influence their experience in any habitat where we work (Winker et al. 2010). Thus, the assertion that an expedition had "taken over the tourist camp to collect birds" is simply an inflammatory characterisation. A total of two sets of vehicles visited this camp during all our time at Nkhotakota NP: one set belonging to the USAID group who provided the assessment of our group's numbers to DLEA, and one set belonging to government officials who came to learn more about our work from our Malawian colleagues. We readily acknowledge that our camps have become larger over the years. The reasons are associated with trying to do more capacity building and collecting more and better data (e.g. parasites and pathogens) with each specimen. This translates to more participants.

Finally, for some of the questions we are interested in, sampling birds around people can be important, as such birds may be those most likely to be linked to pathogens moving to birds from people (and their birds) or to people from birds. We argue that sampling around people is going to be critical for many epidemiological studies, just as sampling in the absence of people (i.e. in protected areas where people are visitors) is critical to assess whether humans or their activities are potentially involved in allowing pathogens to spread.

\section{The role of modern scientific collecting in Malawi}

We have assembled a modern, data-rich sampling for many of Malawi's common species that will allow for many phylogeographic studies using genetic and morphological data. Our projects are documenting previously unknown or non-quantified diversity in Malawian birds that in some cases may best be treated at the species level, but even when only documenting population structure (or the lack of it) these data help highlight the uniqueness of Malawi's avifauna in a way that has never before been demonstrated.

Our more recent work has included some of the most extensive sampling for parasites and pathogens and their hosts that we are aware of for this part of Africa. We have already assembled large molecular datasets on the patterns, prevalence, and diversity of avian malarial parasites, ectoparasites, and helminths from sites in northern and southern Malawi and how parasite 
prevalence correlates with genotype and phenotype of the hosts is an on-going area of research. The sampling we have done includes tissues and specimens preserved in ways that will ensure their utility for a wide variety of future studies (and not only by us).

As comprehensive as Dowsett-Lemaire and Dowsett (2006) is with respect to the current status of Malawi's birds, for many species we have assembled complementary specimen-based sampling that provides a previously unavailable, detailed assessment of the current population biology for Malawi's birds, small mammals, parasites and pathogens (e.g. Engel et al. 2013, Lutz et al. 2015).

\section{The Field Museum should set a better example for conservationists in Malawi}

The final issue is that The Field Museum (and other western institutions) should set an example. Indeed, we agree with this and our long-term devotion to collaboration and capacity-building wherever we work is part of our efforts in Malawi. Despite long-term research by people such as DLEA, the scientific community in Malawi is still far too small to study and teach other Malawians about the challenges associated with biodiversity and conservation in the country. We believe the scientific collecting we have done will help protect isolated forests in Malawi. Across Africa, we and our colleagues continue to build capacity through a variety of avenues including local training, collaboration, support for graduate studies, advising of graduate students, development of materials for education and science communication, workshops about natural history museums, resources for local museums and universities and web-based communication to global audiences. In addition to their research value, specimens are used to communicate to different audiences about the biodiversity of Malawi. We know there is a long way to go with respect to capacitybuilding for science, education and conservation in Malawi, but when DLEA suggest The Field Museum should be setting a better example, we feel that by working with and training our colleagues at the Museums of Malawi and elsewhere on all these fronts, we are helping to lay a foundation for biodiversity and conservation in Malawi, and the collections we have collaboratively assembled will be an important part of that future.

At any site where we work, we are keenly interested in explaining what we are doing and why we are doing it to local workers and park personnel. We see this as setting the best possible example where our message is that collecting has multiple short- and long-term research goals and that these collections will benefit land managers at local and larger landscape scales now and into the future.

In their discussion, DLEA write: "bird distribution can be documented more efficiently and quickly by visual observations complemented, if required, by photographic evidence and taperecordings." This is a debatable point that can be countered based on the literature (e.g. Boakes et al. 2010), but we re-emphasise that this is not an "either/or" question for us, but one of complementarity. As outlined throughout our paper, we obtain much data through scientific collecting that cannot be obtained in other ways. In this vein, we urge our critics to be equally introspective with respect to their own activities. A web site: http://web.uct.ac.za/depts/stats/adu/travel/ malawiozo6.htm where John Wilson, of the Wildlife and Environment Society of Malawi and a DLEA author, showed handing out shotgun shells to local hunters at Lake Chilwa (a Ramsar Wetlands Conservation Site) in 2006 (another season of collecting was done in 2007). Another DLEA author, Lizanne Roxburgh, was also in project pictures on this site. As far as we can tell, no specimens beyond the swabs taken were saved during this project, and certainly no specimens were deposited at the Museums of Malawi (L. Mazibuko pers. comm.). Shot birds apparently were given to the local people for food. The study was focused on sampling for avian flu only and we know of other such sampling in protected areas (including Vwaza Marsh WR) where similar approaches were taken, and no scientific specimens other than swabs were preserved. Does this constitute a threat to the birds of Malawi? Probably not, but it certainly represents a missed opportunity to document avian diversity by not saving specimens. Estimates that thousands of birds are hunted at Lake Chilwa annually are not unreasonable, which means that since 2006, the number of that birds have been harvested there on an annual basis may far exceed the number 
of all avian scientific specimens of all species ever collected in Malawi. We harbour concerns about the ethics of not collecting in a situation like this because of the loss of potentially valuable specimen data and the message sent to local people.

DLEA report that our work in Malawi will go on. We hope to continue research in the country in the future. The collecting we already have done does not answer all the questions that can and should be addressed. Also, building capacity for science in Malawi and elsewhere does not have a term limit to it. In 2011, we held a workshop on natural history museums for the staff from the Museums of Malawi (which has branch museums in cities across the country) that also included participants from the Malawian conservation community (including the Wildlife and Environmental Society of Malawi). There have been government plans underway to construct a new museum in Lilongwe, Malawi's capital, which will have a component of natural history. Collections at such institutions can play a key role in connecting people living in increasingly urban areas to the natural world. Also, in our experience, as in-country capacity grows, there are generally an increased number of questions that come to light and more opportunities and interest for collaborative research with people from other countries. We will continue to work on projects using the specimens that our team has collected in Malawi and we will encourage others to work on these birds as well. We will publish our new results on Malawi's birds in scientific journals; we will provide data and samples to researchers from around the world who are studying a wide variety of questions about birds, their parasites, and pathogens, and they will be able to incorporate these specimens into broader contexts of Africa and the world. Such scientific research may not reach all readers of Bird Conservation International immediately, but we know that a number of the projects will provide information on the taxonomy and status of the birds of Malawi, their parasites and their pathogens that will be of interest and importance to conservation biologists both inside and outside Malawi for years to come.

\section{Conclusion}

DLEA clearly feel that our collecting (and most modern collecting) is a threat. We believe the scientific information presented above illustrates that this is not the case. We have not changed our view that the collecting we do has broad-reaching benefits to both science and conservation and we are confident that we are conducting our scientific collecting in a manner that poses no threat to bird populations.

We agree with Dowsett-Lemaire et al. that the birds of Malawi and elsewhere are under threat, but scientific collecting does not belong on any reasonable list of threats they face. This does not mean our community does not need to be constantly assessing how we are doing our work, but we do that (e.g. Winker et al. 2010). As DLEA note, other human activities, including deforestation (for both timber and firewood), overgrazing by non-native mammals, mining concessions, hunting, pesticides, new pathogens and human population growth all are serious ongoing threats to the biodiversity of Malawi. Our scientific collecting has and will always be done with the conviction that the data can be used directly and indirectly to help do something about these threats now and into the future. One of the greatest threats not on the previous list is a lack of sufficient local scientific capacity and knowledge to get people excited about the birds and other biodiversity around them. A primary goal of our collecting is to provide information that can inform, educate and interest people about biodiversity. DLEA urge the international conservation community to work against (western) museums and (presumably) other entities doing collection-based fieldwork in Africa. DLEA are of course entitled to their opinions on the subject, but we are unwilling to sit by and hope that by watching the avifauna of Malawi and everywhere else in the world that it can survive without the basic knowledge and monitoring that comes through modern scientific collections. Our basic premise is that Malawians (and people everywhere we work) are capable of determining their own conservation goals and how those goals can and should be achieved. We hope to continue to work as closely with African colleagues as we can to help them develop strong research and conservation practices; it also is also why, as DLEA mention, we were willing to meet 
conservation groups about their concerns regarding our work. We urge those interested and active in conservation to consider the broader perspective we present, because our shared goals should be to collectively understand and address the true threats to biodiversity now and into the future. This is what we strive to do.

\section{Acknowledgements}

We thank the Editor for giving us the opportunity to prepare this response and for his editorial comments, but emphasise that the views expressed are ours alone. F. Dowsett-Lemaire, L. Mazibuko, P. Kaliba, D. Steadman, B. Marks, J. Weckstein, J. Engel, S. Hackett provided comments on drafts and their input improved this response.

\section{References}

Bates, J. M. (2000) Allozyme genetic structure and natural habitat fragmentation: Data for five species of Amazonian forest birds. Condor 102: 770-783.

Bates, J. M. (2002) The genetic effects of forest fragmentation on five species of Amazonian birds. J. Avian Biol. 33: 276-294.

Bates, J. M., Bowie, R. C. K., Willard, D. E., Voelker, G. and Kahindo, C. (2004) A need for continued collecting of avian voucher specimens in Africa, or: Why blood is not enough. Ostrich 75: 187-191.

Bowie, C. K. R., Fjeldså, J. Hackett, S. J., Bates, J. M. and Crowe, T. M. (2006) Coalescent models reveal the relative roles of ancestral polymorphism, vicariance, and dispersal in shaping phylogeographical structure of an African montane forest robin. Mol. Phylogenet. Evol. 38: 171-188.

Boakes, E. H., McGowan, P. J. K., Ding, C-q., Clark, N. E., O'Connor, K. and Mace, G. M. (2010) Distorted views of biodiversity: spatial and temporal bias in species occurrence data. PLOS Biology 8: I-I1.

Collar, N. (2000) Collecting and conservation: cause and effect. Bird Conserv. Internatn. 10: 1-15.

Dowsett, R. J. and Dowsett-Lemaire, F. (1984) Breeding and moult cycles of some montane forest birds in south-central Africa. Rev. Ecol. (Terre et Vie) 39: 89-111.

Dowsett, R. J. and Dowsett-Lemaire, F. (1986) Homing ability and territorial replacement in some forest birds in south-central Africa. Ostrich 57: 25-31.

Dowsett, R. J. (1985) Site fidelity and survival rates of some montane forest birds in Malawi, south-central Africa. Biotropica 17: 145-154.
Dowsett, R. J. and Hunter, N. D. (1980) Birds and mammals of Mangochi Mountain, Malawi. Nyala 6: 5-18.

Dowsett-Lemaire, F. and Dowsett, R. J. (2006) The birds of Malawi. Liège, Belgium: Tauraco Press and Aves.

Engel, J. E., Bates, J. M., Weckstein, J. D., Kaliba, P. M., and Gnoske, T. P. (2012) An avifaunal survey of Vwaza Marsh Wildlife Reserve, Malawi. J. East African Nat. Hist. 101: 223-240.

Engel, J. E., Byamana, K., Kahindo, C., Bates, J. M. and Fjeldså, J. (2014) Genetic structure and species limits in the Barred Long-tailed Cuckoo (Cercococcyx montanus) complex. Ibis 330-340.

Kahindo, C., Bates, J. M. and Bowie, R. C. K. (2007) The relevance of data on genetic diversity for the conservation of Afro-montane regions. Biol. Conserv. 134: 262-270.

Lutz, H. L., Hochachka, W. M., Engel, J. I., Bell, J. A., Tkach, V. V., Bates, J. M., Hackett, S. J. and Weckstein, J. D. (2015) Parasite prevalence corresponds to host life history in a diverse assemblage of Afrotropical birds and haemosporidian parasites. PLOS ONE. http:// journals.plos.org/plosone/article?id= 10.1371/journal.pone.0121254. DOI: 10.1371/ journal.pone.0121254

Mortiz, C., Patton, J. L., Conroy, C. J., Parra, J. L., White, G. C. and Beissinger, S. R. (2008) Impact of a century of climate change on small-mammal communities in Yosemite National Park, USA. Science 322: 261264.

Mzumara, T. I., Hockey, P. A. R. and Ridley, A. R. (2012) Re-assessment of the conservation status of Malawi's "endangered" 
Yellow-throated Apails (Apalis flavigularis). Bird Conserv. Internatn. 22: 184-192.

Oatley, G., Voelker, G., Crowe, T. M. and Bowie, R. C. K. (2012) A multi-locus phylogeny reveals a complex pattern of diversification related to climate and habitat heterogeneity in southern African white-eyes. Mol. Phylogenet. Evol. 64: 633-644.

Outlaw, R. K., Voelker, G. and Outlaw, D. C. (2007) Molecular systematics and historical biogeography of the Rock-Thrushes (Muscicapidae: Monticola). The Auk 124: 561-577.

Voelker, G., Outlaw, R. K., Reddy, S., Tobler, M., Bates, J. M., Hackett, S. J., Kahindo, C., Marks, B. D., Kerbis Peterhans, J. and Gnoske, T. P. (2010a) A new species of black boubou from the Albertine Rift (Passeriformes: Laniidae: Laniarius). The Auk 127: 678-689.
Voelker, G., Outlaw, R. K. and Bowie, R. C. K. (2010b) Pliocene forest dynamics as a primary driver of African bird speciation. Global Ecol. Biogeogr. 19: 111-121.

Voelker, G., Bowie, R. C. K. Wilson, B. and Anderson, C. (2012) Phylogenetic relationships and speciation patterns in an African savanna dwelling bird genus (Myrmecocichla). Biol. J. Linn. Soc. 106: 180-190.

Voelker, G., Marks, B. D. Kahindo, C., A'genonga, U., Bapeamoni, F., Duffie, L. E., Huntley, J. W., Mulotwa, E., Rosenbaum, S. A. and Light, J. E. (2013) River barriers and cryptic biodiversity in an evolutionary museum. Ecol. Evol. 3: 536-545. DOI: 10.1002/ece3.482.

Winker, K., Reed, J. M., Escalante, P., Askins, R. A., Cicero, C., Hough, G. E. and Bates, J. M. (2010) The importance, effects, and ethics of bird collecting. The Auk 127: 690-695.

\section{JOHN M. BATES*}

Department of Zoology, Field Museum of Natural History, Chicago, IL 60605, USA.

\section{GARY VOELKER}

Department of Wildlife and Fisheries Sciences, Texas AEM University, College Station, TX 77843, USA.

*Author for correspondence; e-mail: jbates@fieldmuseum.org

Received 4 October 2012; revision accepted 16 January 2014; Published online 6 May 2015 